\title{
WOMEN AT WAR: PUBLIC RELIEF FOR THE LITHUANIAN ARMY, 1918-1920
}

\author{
Mindaugas Sereičikas (iD
}

\begin{abstract}
As the First World War drew to an end, a number of political actors in the east Baltic Sea region declared the independence of new states. This independence had to be defended by their governments in armed conflicts. The army loyal to the Lithuanian government was engaged in active hostilities until the end of 1920. So far, the historiography on these military actions has concentrated on the tactical-operational actions of the armies, and biographical studies of their military leaders. The participation of women in the Lithuanian war of independence and violence by combatants against civilians, including women, have been studied in a rather fragmentary way. This article fills this research gap, by analysing the collective initiatives of women that emerged in Lithuanian society between 1918 and 1920 to provide public relief to the Lithuanian armed forces that were engaged in military operations. By perceiving these initiatives as a response to a military threat, the article seeks to identify the internal and external factors that underpinned the determination of women to provide material assistance to the Lithuanian army. By taking a sociological theoretical approach of stimulus-induced social interaction, it provides an analysis of the reasons for the formation and the development of 13 women's associations, and the nature and the extent of their activities.

KEYWORDS: Lithuanian war of independence; Lithuanian armed forces; public relief to the army; civilian charities; women's associations; civilian-military cooperation.
\end{abstract}

\section{ANOTACIJA}

Baigiantis Pirmajam pasauliniam karui, virtinè politinių aktorių Rytų Baltijos jūros regione paskelbè apie naujų valstybių nepriklausomybę. Šią nepriklausomybę toms vyriausybèms reikèjo ginti ginkluotuose konfliktuose. Lietuvos vyriausybei lojali kariuomenė aktyviuose kariniuose veiksmuose dalyvavo iki 1920 m. pabaigos. Iki šiol istoriografijoje, skirtoje šių karinių veiksmų analizei, koncentruotasi j̣ taktinius-operacinius kariuomenių veiksmus ir karinių lyderių biografinius tyrimus. Moterų dalyvavimas Lietuvos nepriklausomybės kare, kombatantų smurtas, nukreiptas prieš civilius gyventojus, tarp jų moteris, tirtas fragmentiškai. Siekiant užpildyti istoriografinį vakuumą, straipsnyje analizuojamos 1918-1920 m. Lietuvos visuomenejje kilusios moteru kolektyvinès iniciatyvos paremti kariniuose veiksmuose dalyvavusią Lietuvos kariuomenę. Šias iniciatyvas suvokiant kaip reakciją i karinę grèsmę, straipsnyje siekiama nustatyti vidinius ir išorinius veiksnius, lèmusius moteru apsisprendimą materialiai remti Lietuvos kariuomenę. Remiantis sociologijos teorinèmis įžvalgomis apie stimulo paskatintą socialinę sąveiką, straipsnyje analizuojamos 13 moterụ organizacijų kūrimosi priežastys, eiga, jụ veiklos pobūdis ir mastas. PAGRINDINIAI ŽODŽIAl: Lietuvos nepriklausomybès karas; Lietuvos kariuomenė; visuomenès parama kariuomenei; civilių labdaros organizacijos; moterų organizacijos; civilių ir karių bendradarbiavimas.

Mindaugas Sereičikas, mgr., doctoral student, Klaipèda University, Institute of Baltic Region History and Archaeology, Herkaus Manto g. 84, LT-92294 Klaipèda, Lithuania. E-mail: sereicikas.m@gmail.com. 
The historiography of the armed conflicts that took place in Lithuania in 1918-1920, which are referred to as the Wars of Independence, is rather fragmentary in its discussion of women's involvement. The early historiography focuses on an analysis of either individual military units or episodes in the war. Little more than sporadic references to females during the war are to be found in these studies. ${ }^{1}$ There was an increase in the number of publications devoted to the Wars of Independence in the periodical press of the $1930 \mathrm{~s}^{2}$ calling for greater attention to be given to the women who distinguished themselves in war. ${ }^{3}$ With the Second World War impending, side by side with theoretical studies on women's role in a potential war, there appeared in the popular press a growing number of publications about the 'courageous feats of women' during the Wars of Independence. ${ }^{4}$ The common tenet inherent in these publications (which defined the role of women in the Wars of Independence only as engagement and/or distinction in military action) persisted in American-Lithuanian historiography. ${ }^{5}$ Post-1990 research refocused on women's political engagement, ${ }^{6}$ their service in the sanitary corps, and the performance of military intelligence tasks. ${ }^{7}$ Since 2014 , historians have paid more attention to forms of violence by combatants against the civilian population. ${ }^{8}$

NATKEVIČIUS, Ladislovas. Lietuvos kariuomenè. New York, 1919, p. 14-30, 81-119; STEPONAITIS, Vytautas. Karas su bolševikais: Ežerény operacijos. Kaunas, 1920, p. 1-14; Kareivis - Lietuvos gynejjas. Ats. red. Jonas Martynas LAURINAITIS. Kaunas, 1926; JURGELEVIČIUS, Petras. Kauno karo komendantūra, 1919-1929. Kaunas, 1930, p. 5-66; RUŽANCOVAS, Aleksandras. Lenku pulkai mūsų fronte 1919-1920 metais. Kaunas, 1935, p. 1-24; SURGAILIS, Gintautas. Karo archyvo I-XXX tomy bibliografija. Vilnius, 2015, p. 15-23.

2 JOKUBAUSKAS, Vytautas. Periodinio leidinio turinio kiekybinè analizè: 1920-1940 m. "Trimito" atvejis. Istorija, 2019, t. 116, nr. 4, p. 104-105; Gauti aprašymai apie nepriklausomybès kovų dalyvius. Karys, 1937-04-08, nr. 15 (942), p. 395; Mūsų karų ir kariuomenès istorija „KARYJE“. Kario priedas prie nr. 21. Karys, 1934-05-22, nr. 21 (792), p. 116.

3 Redakcijos atsakymai. M. Petruškevičienei. Karys, 1938-02-10-16, nr. 6-7 (985-986), p. 209; Redakcijos atsakymai. Ad. Bučackui. Karys, 1938-03-31, nr. 13 (981), p. 390.

4 DOVYDAITIS, Jonas. Ji atvedè savuosius prie priešo apkasų. Karys, 1937-04-29, nr. 18 (945), p. 479-480; GERULAITIS, Z. Moteris, nepabūgusi kovų ir priešo persekiojimų. Karys, 1937-04-29, nr. 18 (945), p. 477479; BUTKUS, St[asys]. Lietuvos moterys nepriklausomybės karų metu. Mūsų kraštas, 1937-11-19, nr. 47 (202), p. 5; PETRUŠKEVIČIENĖ, M. Moters talka kovų metu. Karys, 1938-05-05, nr. 18 (986), p. 515; B. D. Moterys Tèvynės tarnyboje. XX amžius, 1938-05-14, nr. 14 (563), p. 6; DULSKYTĖ-KINDERIENĖ, Z. Moterys ir kariuomenè. Trimitas, 1938-05-12, nr. 19 (908), p. 464; Koks moterų vaidmuo karo metu. Šeimininke், 1938-05-12, nr. 11, p. 80; SEINŲ PARTIZANAS. Kalèdų „senukas“ neutralioje zonoje. Karys, 1937-12-16-23, nr. 51-52 (978-979), p. 1483-1484; Trys priešo kulkosvaidžiai nenugalèjo 6 lietuvių kareivių. Karys, 193603-26, nr. 13 (888), p. 302-303; B[UTK]US, St[asys]. Moteris, daug padejjusi artimui nelaimèje. Karys, 1936-06-04, nr. 23 (898), p. 560-561; B[UTK]US, St[asys]. Mirè nuoširdi senutè. Karys, 1936-08-13, nr. 33 (908), p. 785; K-NIENĖ, E. Moterys krašto saugumo darbe. Šeimininké, 1937-11-25, nr. 23, p. 169-170.

5 ALIŠAUSKAS, Kazys. Kovos dèl Lietuvos Nepriklausomybès 1918-1920. T. I. Čikaga, 1972, p. 424; RUKŠA, Antanas. Kovos dèl Lietuvos Nepriklausomybès. T. Il. Cleveland, 1981, p. 241-251.

6 JURÉNIENĖ, Virginija. Moteris ir demokratija kuriamoje valstybèje. Parlamento studijos, 2005, nr. 3, p. 77105; TYLA, Antanas. Lietuva prie Vasario 16-osios slenksčio. Vilnius, 2004.

7 LESČIUS, Vytautas. Lietuvos kariuomené 1918-1920. Vilnius, 1998, p. 56, 84, 104, 216-217; LESČIUS, Vytautas. Lietuvos kariuomené Nepriklausomybès kovose 1918-1920. Vilnius, 2004, p. 150, 269; ANUŠAUSKAS, Arvydas. Lietuvos slaptosios tarnybos 1918-1940. Vilnius, 1998, p. 12-14, 33-34; KAVALIAUSKAS, Vilius. Lietuvos karžygiai. Vyties Kryžiaus kavalieriai (1918-1940). T. I-VII. Vilnius, 2008-2015.

8 BALKELIS, Tomas. From Defense to Revolution: Lithuanian Paramilitary Groups in 1918 and 1919. In Paramilitarism in the Eastern Baltics, 1918-1940: Cases Studies and Comparisons (Acta Historica 
An overview of the historiography suggests the existence of two diametrically opposed approaches: women as active participants in military activity, and as victims of unsanctioned violence by the military. However, Stasys Butkus, who served as a non-commissioned officer in the Kaunas garrison headquarters, and had a lot of contact with civilians, wrote in his reminiscences of the 1918-1920 period: 'Women [...] served as nurses attending injured and sick soldiers, organised fundraising activities, distributed relief aid to the men fighting in the trenches, provided meals to hungry soldiers, made clothes, knitted and sent gloves, socks and other items to the frontline, comforted soldiers, and raised their spirits. It was this kind of work that they were mainly engaged in, and it was wholeheartedly appreciated by soldiers. ${ }^{9}$ Colonel Konstantinas Žukas, a former commander-in-chief of the Lithuanian armed forces, described in his memoirs a women's association established in Kaunas in 1919, which provided material support to the Lithuanian army, as an outstanding example of the relationship between civilian society and the military. ${ }^{10}$ In her analysis of the political processes related to the declaration of the independence of Lithuania and the ensuing outbreak of hostilities, Ona Mašiotienè, an active public figure, highlighted women's collective actions aimed at providing support to the Lithuanian armed forces. ${ }^{11}$ The memoirs of various contemporaries suggest that, next to the aforementioned historiographical approaches, there are forms of women's involvement in the Wars of Independence that have been overlooked by historians.

This state of research and complementary evidence by contemporaries serve as a point of departure for a definition of the research question of this article. The war that started in 1914, and was transformed in 1918-1919 as a result of the changing geopolitical situation, impacted societies as a holistic (macro-level) factor. According to the sociologist Anthony Giddens, who has explored the causes of social change, war is a fundamental motor for change in the public and private lives of social groups. ${ }^{12}$ According to Georg Simmel, a classical sociologist and a precursor of

Universitatis Klaipedensis, vol. XXVIII). Ed. by Vytautas JOKUBAUSKAS, Vasilijus SAFRONOVAS, Vygantas VAREIKIS. Klaipeda, 2014, pp. 43-56; BALKELIS, Tomas. War, Revolution and Terror in the Baltic States and Finland after the Great War. Journal of Baltic Studies, 2015, vol. 46, no. 1, pp. 1-9; LAURINAVIČIUS, Česlovas. On Political Terror during the Soviet Expansion into Lithuania, 1918-1919. Journal of Baltic Studies, 2015, vol. 46, no. 1, pp. 65-76; PETRONIS, Vytautas. Neperkirstas Gordijaus mazgas: valstybinès prievartos prieš visuomenę Lietuvoje genezè (1918-1921). Lietuvos istorijos metraštis, 2015/1. Vilnius, 2016, p. 69-95; BALKELIS, Tomas. Lemtingi metai. Lietuva 1914-1923 m. Vilnius, 2019. The research project 'Violence against women: from harassment to crime in 20th-century Lithuania' is being carried out at Vytautas Magnus University in 2018-2021. Sigita Černevičiūté presented part of its results in her presentation 'Violent Soldiers: sexual abuse of women in interwar Lithuania' at the conference 'War and Women' (Klaipeda University, Thomas Mann Cultural Centre, 3-5 September 2020).

9 BUTKUS, S. Lietuvos moterys..., p. 5.

10 ŽUKAS, Konstantinas. Žvilgsnis i praeiț. Chicago, 1959, p. 243.

11 MAŠIOTIENĖ, Ona. Moteru politinis ir valstybiniai-tautiškas darbas 1907-1937 m. Kaunas, 1938, p. 22-23.

12 HEINECKEN, Lindy. The Military, War and Society: The Need for Critical Sociological Engagement. Scientia Militaria: South African Journal of Military Studies, 2015, vol. 43, no. 1, pp. 6-7. 
micro-sociological theory, the totality of interactions among individuals caused by a stimulus (in the present case, war) gives rise to broader social interaction. Collective behaviour is one of the most commonly occurring patterns in the latter. Researchers engaged in the study of 20th-century conflicts have observed that the outbreak of war and its dynamics act on societies as a mobilising factor, promoting the common (joint) engagement of individuals and groups. ${ }^{13}$ Even though the build-up of the threat of war functions as a mobilising factor, the involvement of society subsides with the threat persisting or gradually phasing out. One response by women to the unfolding transformation and the new phase of military activity at the end of 1918 was to band together into associations aiming to provide support and material assistance to the Lithuanian army. The aforementioned women's response is the subject of this research.

The main aim of the article is to provide an answer to the question: what were the reasons for the creation of the associations for material support for the Lithuanian armed forces during the Wars of Independence of 1918-1920? The article achieves this aim in two stages:

1. by identifying the main causes that prompted women to establish associations for the material support of the Lithuanian armed forces;

2. by determining the dynamics of the establishment of women's associations, their geographical distribution, and the nature and the extent of their activities.

The research is based on data from unpublished sources, periodicals, memoirs and historiography. The number of unpublished contemporaneous sources relating to women's associations that came into being during the war ${ }^{14}$ is small. It cannot be excluded that the activities of certain associations were sparsely documented; moreover, it is very likely that some unpublished sources were either destroyed or failed to make their way into museums, libraries and archives. ${ }^{15}$ For example, the records of the Women's War Committee (Motery karo komitetas), one of the first associations of its kind, were kept at its founder's home; however, we have failed to track them

13 LESTER, David. War and Personal Violence. In Effects of War on Society. Ed. by Giorgio AUSENDA. 2nd Ed. San Marino, 2002, pp. 212-213; RASMUSSEN, Anne. Mobilising minds. In The Cambridge History of the First World War. Ed. by Jay WINTER. Vol. 3. Cambridge, 2014, pp. 392-395.

14 The titles of the women's associations instituted in 1918-1920 for the support of the Lithuanian armed forces were diverse and changeable. The women's associations involved in the provision of material support for the Lithuanian armed forces designated themselves as committees, societies, associations, and their chapters, and frequently as circles. This article makes use of the generic term 'association' (with an emphasis on organised, collective action), and in the references to sources, as indicated in the original.

15 The records of institutions in charge of the activities of associations were examined for the purpose of the research (including district administrators, the Police Department and Military Commandant Offices). They contain documents from only some of the women's associations. This further supports the assumption that the activities of women's associations involved in the provision of material support for the Lithuanian armed forces were not always formalised. 
down in the archives while doing this research. ${ }^{16}$ In terms of the availability of data, the main body of unpublished sources on women's associations providing material support to the Lithuanian armed forces in 1918-1920 is stored in the Lithuanian Central State Archives (LCVA). Fund 4 of the Military Sanitation Board contains the correspondence of the military authorities, territorial military administration bodies, and women's associations, and the records of these associations. Fund 929 of the General Staff of the Armed Forces, and Fund 394 of the Ministry of the Interior, contain records related to the activities of women's associations. The availability of data relevant to the research is especially extensive in periodical publications from 1918-1920 and subsequent periods (Lietuva, Vienybè, Kariškių žodis [later Karys], Trimitas, Moteris and Mūsu kraštas). Members of the associations gave accounts of their activities and published their memoirs in these periodicals. In addition to the two aforementioned sets of sources, the study made use of the memoirs of leaders and active participants in women's associations. The memoirs of soldiers also provide fragmentary information on the material assistance rendered by individual females in the Lithuanian military, but we have made minimal use of evidence from these memoirs. Firstly, the memoirs mention next to nothing about the support made available on an organised basis; secondly, the memoirs by women who were actively engaged in the activities of support associations provide more comprehensive and better-quality data, in contrast to the memoirs of males (soldiers), who observed the developments pertinent to the study from the sidelines, and only fragmentarily. It is furthermore important to remark that extant records allow for a more in-depth analysis of the involvement by Lithuanian women, while there is a lack of data relevant to a comprehensive analysis of the activities of women of other nationalities. These limitations make it hard to arrive at unambiguous conclusions regarding the involvement of women of other national backgrounds in the provision of material support for the Lithuanian armed forces.

The first initiatives aimed at the support of an incipient Lithuanian army in Vilnius

The first joint initiatives by women in Vilnius, a city which became a central point for the formation of the newly created Lithuanian armed forces in October to December 1918, were instigated by their personal determination to support the political projection of an independent Lithuania. The Defence Commission (Apsaugos komisija), constituted by the State Council of Lithuania (Lietuvos valstybès taryba) in Vilnius on 8 October 1918, organised an assembly of soldiers returning to Lithuania that was to become the embryo

16 MAŠIOTIENĖ, O. Op. cit., p. 22-24. 
of the Lithuanian armed forces. Several women who supported the idea of an independent Lithuanian state attended the assembly. However, they were disappointed with the small number of female participants, and initiated a recruitment campaign. From 24 October 1918, Aldona Čarneckaitè, Birutè Grigaitytè and Marcelè Kubiliūtè mounted publicity campaigns, and drew up lists of men able and willing to serve in the Lithuanian army at various gatherings, coffee shops and other public venues. ${ }^{17}$

The initiatives of women coincided with the efforts in search of aid by representatives of the incipient Lithuanian armed forces. Relying on their social contacts, the promoters of the cause of the Lithuanian armed forces did their best to involve women, as potential facilitators, in the effort to create a military force. In parallel, women supporting the political projection of an independent Lithuania were committed to contributing to the cause of the creation of an independent state, and looked for possibilities for joint action. At the end of 1918, Liudas Gira was one of the promoters of interaction between the Lithuanian army and women, based on concurrent interests. Within the Defence Commission, Gira was given the task of overseeing the organisation of intelligence, and, by making use of his contacts, he created a woman-based informer network. In his memoirs, Gira said that women were serious in their resolution to take part in gathering information, but the author of the initiative was himself highly critical of the usefulness of the network created. ${ }^{18}$ After Gira was appointed to the post of city commandant, Viktorija Landsbergienè, a social activist, offered him assistance. A team composed of about 12 women that had been assembled by Landsbergienè was engaged in collecting medicines and clothes and cooking for the Office of the Commandant of Vilnius. ${ }^{19}$ Ona Mašiotienè brought together the first initiatives, and under her coordination the Women's War Committee was established in Vilnius on 22 November 1918. Chaired by Mašiotienè, and including about ten women in its early stages, the Committee set about providing multi-faceted support to the incipient Lithuanian armed forces as its principal task. ${ }^{20}$

At the end of 1918, the initiatives for providing material support through cooperation between women and the Lithuanian armed forces relied on women who had been involved in public and political life over a prolonged period. The first initiators of women's groups that were devoted to an organised fundraising effort for the benefit of the Lithuanian army were not only involved in the national revival movement but also had extensive experience of social activities, especially charity work. The leaders of women's associations that were engaged in fundraising activities for the benefit of the Lithuanian armed forces between 1918 and 1920 had participated in the activities of Lithuanian war relief associations. One of the first women's groups involved in the provision of organised material support for the incipient Lithuanian army was initiated by Landsbergienè, who chaired the

17 Ibid., p. 22-24.

18 ANUŠAUSKAS, A. Op. cit., p. 12-14.

19 BELICKIENĖ, Ona. Lietuvès Vilniaus Golgotoje. Naujoji Vaidilutė, 1938, nr. 8-9 (154-155), p. 416.

20 MAŠIOTIENĖ, O. Op. cit., p. 22-24. 
Vilnius Lithuanian War Relief Committee (Vilenskii Litovskii Komitet vspomoshchestvovaniia postradavshim ot voiny) in 1914-1915. ${ }^{21}$ The above-mentioned Mašiotienè was one of the first founders of Lithuanian women's associations who had been involved in the national movement, and her husband Jonas Mašiotas was a member of the Lithuanian War Relief Committee (Litovskoe obshchestvo po okazaniiu pomoshchi postradavshim ot voiny) in 1916-1918.22

However, it should be said that the previous expertise of women's charitable work was utilised to a limited extent at the end of 1918. The pre-First World War beginnings of organised charitable activities on a wider scale are linked to the founding of the first women's associations. The women's associations that were established at the beginning of the 20th century, although representing different ideologies, were focused primarily on self-education in their charitable work. For example, one of the first women's associations, the Lithuanian Catholic Women's Association (Lietuvos katalikių moteru draugija), the largest in terms of membership, opened schools and set up training courses for teaching girls. ${ }^{23}$ With the outbreak of the First World War, the nascent tradition of charitable activities ceased, because the majority of women who were involved in organising these activities had departed for the interior of the Russian Empire. The hostilities also considerably affected the nature of charity work. The activities of the Lithuanian War Relief Committee which operated during the First World War, and the charity work by women that resumed after 1918, were directed primarily at the protection of vulnerable groups. ${ }^{24}$ Women's associations endeavoured to address social issues and provide material support to the most vulnerable groups in the immediate aftermath of the war. ${ }^{25}$

\section{A turning point: a personal appeal by the army}

Following the withdrawal of the nascent Lithuanian military units from Vilnius, the Vilnius-based short-term relationships dependent on social capital between women involved in public and political processes and men who had joined the Lithuanian

21 ALIŠAUSKAS, K. Op. cit., p. 4-5; BELICKIENĖ, O. Op. cit., p. 414. Cf. SAFRONOVAS, Vasilijus; JOKUBAUSKAS, Vytautas; VAREIKIS, Vygantas; VITKUS, Hektoras. Didysis karas visuomeneje ir kultūroje: Lietuva ir Rytu Prüsija. Klaipèda, 2018, p. 130-132.

22 YČAS, Martynas. Rusijos lietuvių pastangos kovose už Lietuvos nepriklausomybę. In Pirmasis nepriklausomos Lietuvos dešimtmetis 1918-1928. Kaunas, 1930, p. 21-33.

23 DOGELIS, Pranas. Katalikių moterų organizuoto darbo pradžia. In Tiesos ir meilés tarnyboje: Lietuviu katalikiy motery draugija 1908-1933. Red. Ona BELECKIENĖ-GAIGALAITĖ. Kaunas, 1933, p. 30-35; MAŠIOTIENĖ, O. Op. cit., p. 6.

24 KARVELIENĖ, Veronika. Socijalinés globos sekcijos. In Tiesos ir meilés tarnyboje..., p. 80-96.

25 GRIFFANTE, Andrea. Children, Poverty and Nationalism in Lithuania, 1900-1940. London, 2019, pp. 109116; Lietuvos moteru globos komiteto susirinkimu protokolai, 1919-05-27-1920-12-01. Lietuvos centrinis valstybés archyvas (Lithuanian Central State Archives, LCVA), f. 1063, ap. 1, b. 2, I. 1-27. 
armed forces soon broke up. After the retreat of the Lithuanian troops, most of the more active women stayed behind in Vilnius, and an initiative for further cooperation was undertaken by individual units of the Lithuanian armed forces in the making. With the Lithuanian armed forces having relocated to Kaunas and Alytus, the Lithuanian military authorities embarked on a search for resources necessary for the conduct of military operations. With the Red Army approaching Kaunas, in addition to the recruitment of volunteers, the Ministry of National Defence appealed to women with a call to support the Lithuanian army. ${ }^{26}$ Simultaneously, representatives of Christian public and political organisations campaigned for the establishment of associations aimed at providing support for the Lithuanian armed forces. Female members of the Lithuanian Christian Democratic Party, from the very outset of the military action, appealed to women not to wait on the sidelines, and get involved in providing full support for the Lithuanian armed forces: to donate food and clothing, to offer psychological assistance, and to encourage men to join the army. The appeal claimed that: 'If only we, the women of Lithuania, wanted it, the army of Lithuania would get all the supplies it might need.'27 The Lithuanian Catholic Women's Association declared in Lietuva, the official newspaper of the government of Lithuania, that it was the duty of each woman to provide support for the Lithuanian armed forces in the face of war. ${ }^{28}$ Recurrent statements called on women to sacrifice money set aside for the purchase of 'expensive silks' for the Lithuanian army, to donate food and clothes, and organise free entertainment events for the soldiers. To make these activities more efficient, they were encouraged to organise themselves into associations or committees, and to establish relations with representatives of the military authorities. ${ }^{29}$ The Lithuanian Red Cross Society (Lietuvos raudonojo kryžiaus draugija), founded on 12 January 1919, also urged women to provide support, calling on them not only to assist in providing food and necessities to the soldiers, but also to contribute to the establishment of hospitals in various towns. ${ }^{30}$

However, the appeals in the press did not receive a broad response. By the autumn of 1919, only a few women's associations seeking to help the Lithuanian armed forces had been established. ${ }^{31}$ The situation changed in the autumn of 1919. On a visit to the regions of the country, Colonel Vladas Nagevičius, the field sanitary inspector of the Lithuanian army, encouraged women to set up associations to provide material support for the Lithuanian army. Moreover, Sofija Kymantaitè-Čiurlionienè, who was employed in the Press and Education Department of the General Staff of the

26 KRAŠTO APSAUGOS MINISTERIJA. Lietuvos moterys! Tiesos kardas, 1919-01-11, nr. 4, p. 1.

27 VARGO BITĖ. Moterų balsas. Tiesos kardas, 1919-02-01, nr. 22, p. 2.

28 L[IETUVIŲ] K[ATALIKIŲ] MOTERŲ DRAUGIJA. Atsišaukimas j Lietuvos moteris. Lietuva, 1919-04-09, nr. 74, p. 2.

29 LIETUVAITE். I seses verpèjèles audèjèles. Vienybé, 1919-09-17, nr. 38, p. 304-305.

30 NATKEVIČIUS, L. Op. cit., p. 158-159.

31 Panevéžio katalikių moterų kareiviams šelpti komitetas. Karys, 1938-12-22, nr. 51, p. 1479. 
Lithuanian Armed Forces, travelled across Lithuania with Colonel Nagevičius, calling for organised support for the army. ${ }^{32}$ Elena Stankevičaitè, the chairwoman of the Women's Circle for Soldiers' Relief in Vilkaviškis (Vilkaviškio moteru ratelis kareiviam šelpti), in her memoir on the establishment of the circle wrote: 'After a short speech about our young army, General Nagevičius ${ }^{33}$ described its rather poor condition, and pleaded with all the ladies to join forces in providing material support for the young army, which defends our freedom, pointing out meanwhile that the state itself, still being in its formative stages, was incapable of ensuring adequate supplies without public support. ${ }^{34}$ In addition to Vilkaviškis, ‘notable local women, Lithuanian ladies as well as polonised ones and Jewish ladies ${ }^{\prime 35}$ were invited to attend meetings initiated by Colonel Nagevičius in Kèdainiai, ${ }^{36}$ Kaišiadorys and Kalvarija. At these meetings, Colonel Nagevičius gave the women information about the Lithuanian armed forces, and updated them on the situation on the front line, and, in his appeal for help, suggested that women's committees be established. ${ }^{37}$ This presumably personal initiative of Colonel Nagevičius was driven by the realities in the Lithuanian armed forces: there was a crisis in the sanitary division of the army in the autumn of 1919, due to the severe lack of medical personnel and facilities for the medical treatment and the care of soldiers. The supply department of the Lithuanian armed forces was not in a position to satisfy these needs, and Colonel Nagevičius therefore appealed to the general public for assistance, and to women in particular. ${ }^{38}$

The determination of women to become involved in collective initiatives aimed at material support for the Lithuanian armed forces was inspired by kinship, by family and social ties. Women who had interacted with officers of the armed forces and later married them were actively involved in provisional associations engaged in fundraising for the benefit of the army. ${ }^{39}$ At the end of 1919, the leaders of provisional associations supporting the Lithuanian armed forces included: Stefanija Paliulytè, the future wife of Brigadier General Kazys Ladiga, ${ }^{40}$ Leokadija Januševičiūtè, the

32 Sofijos Čiurlionienès nuopelnai mūsų kariuomenei, 1929-07-08. LCVA, f. 384, ap. 3, b. 170, I. 208-210.

33 The author of the memoir cites the military rank of Nagevičius inaccurately. In the autumn 1919, when on a visit to Vilkaviškis, Nagevičius held the rank of sanitary service colonel, while the rank of lieutenant general was awarded on 20 May 1920.

34 STANKEVIČAITÉ, Elena. Vilkaviškio moterų ratelis kareiviams šelpti. Karys. 1930-01-09, nr. 2 (554), p. 25-26.

35 AKMENINIS. Iš Lietuvos. Vienybė, 1919-12-25, nr. 51, p. 409-410.

36 Kèdainių moteru komiteto tèvynei ginti pranešimas nr. 73 Sanitarijos skyriaus viršininkui, 1920-11-09. LCVA, f. 4, ap. 1, b. 21, I. 7.

37 Suvalku Kalvarija. Kariškiu žodis, 1919-10-24, nr. 23, p. 179-180; AKMENINIS. Iš Lietuvos. Vienybè, 1919-12-25, nr. 51, p. 409-410.

38 INGELEVIČIUS, Vladas. Gen. gyd. VI. Nagevičius Lietuvos kariuomenès sveikatos sargyboje. In Generolo gydytojo Vlado Nagiaus Nagevičiaus gyvenimo ir darbu ap̌̌valga. Red. Balys MATULIONIS. Putnam, 1962, p. 229-231.

39 BELICKIENĖ, O. Op. cit., p. 416.

40 JANKAUSKAS, Vidmantas. Kario kelias. Generolas Kazimieras Ladiga nepriklausomybès kovose. Vilnius, 2004, p. 20-21. 
future wife of Brigadier-General Jonas Juodišius, ${ }^{41}$ and Marija Gruzdaite, the future wife of Major Petras Gudelis. ${ }^{42}$ After her brother volunteered for the army, Sofija Steikūnaitè, the future wife of the officer Jonas Puikūnas-Pupkis, ${ }^{43}$ became involved in raising material support (food and clothing) and its delivery to the front line. ${ }^{44}$

The impact of social ties on the creation of associations is further corroborated by instances of the provision of material support to actual units in the Lithuanian armed forces. The material support raised by women's associations was usually handed over to army units that were deployed in the areas where these associations operated, or in which family members of the women involved in the activities of the associations served. ${ }^{45}$ For instance, a women's committee based in Panevèžys from July 1919 supplied warm clothing and other necessities to the soldiers of the 4th Infantry Regiment. ${ }^{46}$ This regiment was formed in Panevezžys, and participated in military action around Panevėžys, Kèdainiai and Ukmergè. ${ }^{47}$

National identity was a significant factor in the formation of the women's collective initiatives in question, although not a determinant. It should be noted that the membership of associations operating in larger towns and cities included members of different national and ethnic backgrounds. The associations that were most active in 1919 and 1920 were based in Kaunas and Panevėžys, whose membership (including their governing bodies) was composed of members of all national communities. ${ }^{48}$ Jewish women participated in the activities of several associations active in 1919 and 1920. According to the historian Eglè Bendikaitè: 'The active involvement of Jewish women in Panevéžys stands out visibly in the general context of Lithuania of that period. ${ }^{49}$ In addition to their active and effective participation in the elections to the Jewish Community Council, they became quite actively involved in the activities of the Panevezžys Women's Association for the Support of the Lithuanian Armed Forces. The core of the Association, which was especially active in providing material assistance to the army in 1920, included nine Jewish women residents of Panevezžys. Twelve Jewish women, four of whom were elected to the governing bodies of the Association, were members of the steering group of the Women's Association established in

41 Juodišius Jonas. In ASEVIČIUS, Vytautas, et al. Lietuvos kariuomenés karininkai 1918-1953. T. IV. Vilnius, 2004, p. 99-100.

42 Gudelis Petras. In ASEVIČIUS, V., et al., Op. cit. T. III. Vilnius, 2003, p. 243-244.

43 Puikūnas-Pupkys (Pupkis) Jonas. In ASEVIČIUS, V., et al., Op. cit. T. VI. Vilnius, 2006, p. 175.

44 PETRUŠKEVIČIENĖ, M. Moters talka kovų metu. Karys, 1938-05-05, nr. 18 (986), p. 515.

45 Vilkaviškio miesto komendanto raštas nr. 211 Sanitarijos skyriaus viršininkui, 1920-09-15. LCVA, f. 4, ap. 1, b. 21, I. 31-32.

46 A. Iš Panevěžio L[ietuvių] K[atalikių] gyvenimo. Moteris, 1921, nr. 5, p. 11-12.

47 LESČIUS, V. Lietuvos kariuomenè 1918-1920..., p. 248-249.

48 Iš Lietuvos gynimo komiteto. Lietuva, 1920-10-07, nr. 217 (499), p. 1.

49 BENDIKAITĖ, Eglè. "Lai kalba žygiai ir faktai“: Panevéžio krašto žydai Nepriklausomybės kovose. In Iš Panevéžio praeities: Lietuvos nepriklausomybés gynejjai ir puoselétojai. Sud. Donatas PILKAUSKAS, Zita PIKELYTĖ. Panevėžys, 2018, p. 78. 
Kèdainiai in the late autumn of 1919 with the assistance of the commandant Juozas Šarauskas. ${ }^{50}$ A third (four out of 12) of the membership of the steering group of the Kaišiadorys Women's Association was made up of Jewish women. ${ }^{51}$ A Jewish woman, Rabinavičienè, was elected to the Board of the Lithuanian Women's Committee to Protect the Homeland that was constituted in October 1920.52

During the period under consideration, it was only in Jonava that an association for the relief of the Lithuanian army counted exclusively members of national minorities among its founders. On 14 November 1920, Jews opened a meal station in Jonava, to the operation of which the Jewish Community Council contributed an amount of 20,000 Lithuanian auksinas. Volunteer Jewish women from Jonava worked in the canteen, which attracted 12 to 106 soldiers on a daily basis. ${ }^{53}$ The exclusive case of Jonava can be explained by the national composition of the town's population. According to the 1923 census data, the population of Jonava was 4,100, including 2,700 Jews (65.9\% of the total population). Compared with other settlements with a population of over 2,000 , Jonava boasted the largest Jewish population in relative terms. ${ }^{54}$

The involvement of women of Polish and German backgrounds was visibly lower. The women's committee constituted in Kaunas in late 1919 at the instigation of Colonel Nagevičius was chaired by a German woman called Eichelberg, the wife of a Lutheran pastor; 55 and another German lady, V. Eschmann, served on the Board of the Lithuanian Women's Committee to Protect the Homeland (Lietuvos motery komitetas Tèvynei ginti). ${ }^{56}$ At least two women's associations, those of Kaišiadorys and Kalvarija, had Polish women in their membership. In 1920, women of Polish nationality established an association in Ukmergè, which provided material support only for Polish soldiers who fought in the ranks of different armies. ${ }^{57}$

A combination of different internal and external factors led to the involvement of women in associations whose purpose was to support the Lithuanian armed forces in the period from 1918 to 1920. At the outset of the period under consideration, the previous experience of the women was more important, especially experience gained in charity work. With the increasing numbers of Lithuanian troops (in early January 1919, the

50 Žydu moteris kovose dèl Lietuvos Nepriklausomybès. In Skydas, 1918-1923. Ats. red. Moisiejus BREGŠTEINAS. Kaunas, 1934, p. 31.

51 AKMENINIS. Iš Lietuvos. Vienybè, 1919-12-25, nr. 51, p. 409-410.

52 MAŠIOTIENĖ, O. Op. cit., p. 28.

53 Steigiamojo Seimo narès Salomèjos Stakauskaitės raštas Dèl kareivių maitinimo punkto, 1920-12-06. LCVA, f. 4, ap. 1, b. 21, I. 5.

54 TRUSKA, Liudas. Lietuviai ir žydai nuo XIX pabaigos iki 1941 m. birželio. Vilnius, 2005, p. 91.

55 ŽUKAS, K. Op. cit., p. 243.

56 MAŠIOTIENË, O. Op. cit., p. 28.

57 Steigiamojo Seimo narès Salomèjos Stakauskaitès raštas Vyriausiajam Lietuvos gynimo komitetui, 1920-12-06. LCVA, f. 4, ap. 1, b. 21, I. 4. 
troops included about 3,000 soldiers, ${ }^{58}$ whereas in the autumn of 1920, armed forces personnel amounted to about $40,000^{59}$ ), the social ties and the initiative of the military community gave rise to collective initiatives on the part of women.

The dynamics of military operations, the nature and extent of the activities of women's associations

At the end of 1918, the extent of women's collective initiatives in Vilnius was relatively low. The small scale of cooperation was mainly due to the rather limited potential, there being few actively engaged women, and given the fact that the same women were involved in both initiatives. From the second half of 1919, in the wake of the appeals made by members of the military community, there was a growth in the scale of women's collective initiatives. In 1918-1920, there were 13 women's associations engaged in relief activities for the benefit of the Lithuanian armed forces in different urban areas of Lithuania (cf. Table 1). The aim of these associations was to engage as many women living in the area as possible.

In terms of geographical coverage, the women's associations spanned a considerable part of the area under the control of the Lithuanian army. These associations were based in the larger towns (with a population of 5,000 and more), control of which had recently been taken by the Lithuanian armed forces, and in smaller towns (with a population of 2,000 to 5,000) in which either Lithuanian troops were deployed or through which logistical supply chains ran. Out of the ten largest urban centres in terms of population, the six cities (Kaunas, Panevėžys, Ukmergè, Marijampolè, Kèdainiai and Vilkaviškis) had active women's associations involved in providing material support to the Lithuanian army in 1919 and 1920. The lowest presence of associations active in providing material support to the armed forces was in the northern part of Lithuania. Judging by the extant fragmentary records, the initiative to establish a women's association in Mažeikiai in early 1920 failed. ${ }^{60}$ Research has furthermore proven the lack of any data showing the presence, albeit short-lived, of women's associations in Mažeikiai or other towns in northern regions of Lithuania.

58 STATKUS, Vytenis. Lietuvos ginkluotosios pajėgos 1918-1940 m. Čikaga, 1986, p. 33.

59 SURGAILIS, Gintautas. Lietuvos kariuomené 1918-1998. Vilnius, 1998, p. 20.

60 Mažeikių karo komendanto telegrama nr. 15 Sanitarijos skyriaus viršininkui, [be datos]. LCVA, f. 4, ap. 1, b. 21, I. 23; Šiaulių miesto ir apskrities komendanto raštas nr. 932 Sanitarijos skyriaus viršininkui, 1920-02-17. LCVA, f. 4, ap. 1, b. 21, I. 24. 
Table 1. Women's associations providing material support to the Lithuanian armed forces, $1918-1920 .{ }^{61}$

\begin{tabular}{|c|c|c|c|}
\hline No. & $\begin{array}{l}\text { Date and place of } \\
\text { establishment }\end{array}$ & Area covered & Scope of activities \\
\hline 1. & $\begin{array}{l}\text { 22.11.1918, } \\
\text { Vilnius* }\end{array}$ & $\begin{array}{l}\text { Vilnius and its surrounding } \\
\text { area }\end{array}$ & $\begin{array}{l}\text { Fundraising, recruitment campaign } \\
\text { promoting enrolment in the } \\
\text { Lithuanian armed forces }\end{array}$ \\
\hline 2. & $\begin{array}{l}\text { 15.07.1919, } \\
\text { Panevéžys }\end{array}$ & $\begin{array}{l}\text { The city and district of } \\
\text { Panevėžys (chapters active in } \\
\text { Linkuva and Naujamiestis) }\end{array}$ & $\begin{array}{l}\text { Fundraising, opening of a meal } \\
\text { station, short nurse training courses, } \\
\text { support for civilian and military } \\
\text { hospitals in Panevėžys }\end{array}$ \\
\hline 3. & $\begin{array}{l}\text { 17.09.1919, } \\
\text { Kalvarija }\end{array}$ & Kalvarija & $\begin{array}{l}\text { Fundraising, organisation of } \\
\text { entertainment and educational events }\end{array}$ \\
\hline 4. & \begin{tabular}{|l|} 
22.09.1919, \\
Vilkaviškis \\
\end{tabular} & $\begin{array}{l}\text { Vilkaviškis and adjacent rural } \\
\text { districts }\end{array}$ & $\begin{array}{l}\text { Fundraising, organisation of } \\
\text { entertainment and educational events }\end{array}$ \\
\hline 5. & \begin{tabular}{|l|} 
21.09.1919, \\
Marijampolè
\end{tabular} & $\begin{array}{l}\text { Marijampolè and adjacent } \\
\text { rural districts }\end{array}$ & $\begin{array}{l}\text { Fundraising, support for the Third } \\
\text { Field Hospital }\end{array}$ \\
\hline 6. & $\begin{array}{l}\text { 29.11.1919, } \\
\text { Kèdainiai }\end{array}$ & $\begin{array}{l}\text { Kèdainiai and adjacent rural } \\
\text { districts }\end{array}$ & $\begin{array}{l}\text { Fundraising, support for the Second } \\
\text { Field Hospital in Kedainiai, the First Field } \\
\text { Hospital in Baisogala, and the Third Field } \\
\text { Hospital in Alytus, operating a canteen }\end{array}$ \\
\hline 7. & $\begin{array}{l}01.12 .1919, \\
\text { Kaišiadorys }\end{array}$ & Kaišiadorys & $\begin{array}{l}\text { Fundraising, organisation of } \\
\text { entertainment and educational events }\end{array}$ \\
\hline 8. & $\begin{array}{l}\text { Late } 1919, \\
\text { Kaunas** }\end{array}$ & Kaunas & $\begin{array}{l}\text { Fundraising, organisation of } \\
\text { entertainment and educational } \\
\text { events, support for a military hospital }\end{array}$ \\
\hline 9. & $\begin{array}{l}\text { Late 1919, } \\
\text { Šeduva** }\end{array}$ & Šeduva & Meal station \\
\hline 10. & $\begin{array}{l}\text { Late 1919, } \\
\text { Ramygala** }\end{array}$ & Ramygala & Fundraising \\
\hline 11. & $\begin{array}{l}\text { Early October } \\
\text { 1920, } \\
\text { Ukmerge }{ }^{\star \star}\end{array}$ & $\begin{array}{l}\text { Ukmergè and adjacent rural } \\
\text { districts }\end{array}$ & $\begin{array}{l}\text { Fundraising, support for the hospitals } \\
\text { in the city and in the adjacent area, } \\
\text { opening of a meal station }\end{array}$ \\
\hline 12. & $\begin{array}{l}\text { 14.11.1920, } \\
\text { Jonava }\end{array}$ & Jonava & Meal station \\
\hline 13. & $\begin{array}{l}\text { 1920, ** } \\
\text { Radviliškis }\end{array}$ & Radviliškis & Fundraising, meal station \\
\hline
\end{tabular}

* Organised activities terminated in early 1919.

** The precise date of establishment is undetermined.

61 Sources: Panevéžio katalikių moterų kareiviams šelpti komitetas. Karys, 1938-12-22, nr. 51, p. 1479; MAŠIOTIENĖ, O. Op. cit., p. 22-24; Gen. Itn. Vlado Nagevičiaus telefonograma nr. 797/c Kèdainių karo komendantui, 1920-11-13. LCVA, f. 4, ap. 1, b. 21, I. 9; Vilkaviškio miesto komendanto raštas nr. 211 Sanitarijos skyriaus viršininkui, 1920-09-15. LCVA, f. 4, ap. 1, b. 21, I. 31-32; Kaišiadorių miesto kronika [interaktyvus], [žiūrèta 2020-10-12]. Prieitis per internetą: <http://www.kaisiadoriumuziejus.lt/ kaisiadoriu-bibliografija/kaisiadoriu-miesto-kronika/1900-1920/>; ŽUKAS, K. Op. cit., p. 243; KUBILIUS, K[azys]. Laiškas i L. k. moterų draugijos Ramygalos skyrių. Lietuva, 1919-12-18, nr. 272, p. 4; Kalvarijos moterų komiteto pranešimas, 1920-02-22. LCVA, f. 4, ap. 1, b. 21, I. 15; Steigiamojo Seimo narès Salomejos Stakauskaitès raštas Dèl kareivių maitinimo punkto, 1920-12-06. LCVA, f. 4, ap. 1, b. 21, I. 5; KOMITETO NARYS. Marijampolè. Lietuva, 1919-12-30, nr. 281, p. 3; Žinios iš Lietuvos. Lietuva, 1919-10-17, nr. 230, p. 2; Moterų komitetai kareiviams šelpti. Lietuva, 1919-12-16, nr. 271, p. 1-2; Privatiniai Lietuvos moterų komitetai aprūpinti kareiviams skalbiniais. Lietuva, 1919-10-30, nr. 214, p. 2. 
An analysis of the data collected during the research suggests that the principal activities of all these associations included the collection of basic commodities (clothing and food) and their provision to the Lithuanian armed forces. Women donated items, food and clothing from their households, and organised the collection of material goods needed by the troops by making rounds of local communities. In the autumn of 1919, the Lithuanian army experienced a severe shortage of warm clothing (gloves, socks, headgear and warm underwear), and therefore the newly created women's associations paid particular attention to meeting these needs. In 1919, the Panevėžys Committee of the Lithuanian Catholic Women's Association for the collection of donations for soldiers on the front line and in hospitals despatched warm headgear to the 1st and 2nd battalions of the 4th Infantry Regiment. In 1920, the Committee carded 17 poods of wool, and, after spinning it, made gloves, socks and warm underwear, which were sent to soldiers on the front line. ${ }^{62}$ Members of an ad hoc society for soldiers' relief recently established by women in Kalvarija (Kalvarijos miesto moteru laikinoji draugija kareiviams pagelbèti, later the Kalvarija Women's Committee, or Kalvarijos moteru komitetas) handed over home-made clothing (14 shirts and nine pairs of underpants) to the 3rd Company of the 1st Reserve Battalion, and received a message of thanks on behalf of the company from the commander, Lieutenant Juozas Prūsaitis. ${ }^{63}$ The women of Kalvarija also arranged a fundraising campaign and a theatrical performance, and, using the funds collected, purchased clothes necessary for the troops which were donated to the 3rd Machine-Gun Platoon fighting against Polish troops. ${ }^{64}$ The Kaišiadorys Women's Committee for Soldier's Relief (Kaišiadorių moteru komitetas kareiviams šelpti) organised a fundraising campaign in December 1919, and bought clothing the troops needed with the collected amount of 1,261 auksinas. ${ }^{65}$ In a similar fashion, the Kèdainiai Women's Committee for Soldiers' Relief (Kèdainių moterų komitetas kareiviams šelpti) organised a 'collection of warm clothing and other donations for the soldiers' across the entire Kèdainiai area. The items collected were delivered to the Daugavpils front on 14 January 1920, on the instructions of the Sanitary Department of the Ministry of National Defence. ${ }^{66}$

Some women's associations rendered a range of assistance to military and civilian hospitals where soldiers in the Lithuanian armed forces were being treated. In addition to the Central Military Hospital in Kaunas, there were three military field hospitals in operation in 1919 and 1920.67 Members of women's associations pro-

62 Panevéžio katalikių moterų kareiviams šelpti komitetas. Karys, 1938-12-22, nr. 51, p. 1479.

63 Intendantūros sandèlio nr. 7 Kalvarijoje kvitas, 1919-09-24. LCVA, f. 4, ap. 1, b. 21, I. 12.

64 Kalvarijos moterų komiteto pranešimas, 1920-02-22. LCVA, f. 4, ap. 1, b. 21, I. 15.

65 AKMENINIS. Iš Lietuvos. Vienybe், 1919-12-25, nr. 51, p. 409-410.

66 Kèdainių moterų komiteto tèvynei ginti raštas nr. 73 Sanitarijos skyriaus viršininkui, 1920-11-09. LCVA, f. 4, ap. 1, b. 21, I. 7.

67 LUKMINAITĖ, Solveiga. Karo sanitarijos tarnybos veikla Nepriklausomybès kovų metu (1919-1923 m.). Vytauto Didžiojo karo muziejus 2018 metais. Almanachas. Kaunas, 2019, p. 29-33. 
vided volunteer services and material support to every military hospital. The original purpose of one of the first women's committees, founded in July 1919 in Panevėžys, was to provide care for soldiers undergoing treatment in Panevėžys military hospital. The committee members arranged short courses in nursing, collected and distributed food in the hospital, supplied the hospital with the necessary furniture and bed linen, delivered tobacco, books and newspapers, and provided burial gowns for deceased soldiers. ${ }^{68}$ Ona Pabedinskaitè, a member of the Panevėžys Committee, wrote in her memoirs: 'At that time, there was a severe shortage of everything in the hospital. It was women who noticed it and immediately took steps to deal with it [...] Bed linen and pillows were scarce in the hospital. The women collected a lot of such items, and made donations in large quantities. ${ }^{69}$ Women's committees also provided clothes to soldiers in the Lithuanian army who were discharged from military hospitals where they had been treated. In November 1920, the Kèdainiai Women's Committee received an urgent request from the army for clothing for recovered soldiers due to be discharged from the Third Field Hospital in Alytus. Due to a lack of clothes, the recovered soldiers were unable to leave hospital, and occupied beds needed for the treatment of the sick. ${ }^{70}$ The women's association that was active in Ukmergè, using donations and its members' private funds, provided food and clothing to Lithuanian army soldiers in transit, and to those being treated in the two hospitals in Ukmergè (for example, 58 soldiers in the Lithuanian army underwent treatment in Ukmergè on 4-5 December 1920). The association paid a salary to the nurse on duty at the Ukmerge district hospital. It should be added that in the autumn of 1920, soldiers wounded in the fighting against the Polish army were transported to Ukmergè. ${ }^{71}$

Furthermore, women's associations opened and maintained meal stations and canteens, and organised a wide range of events for the benefit of soldiers in the Lithuanian army. Canteens were set up at railway stations and in the larger towns. More than half of the women's associations operating in 1918-1920 ran meal stations and canteens (see Table 1). The number of soldiers visiting these canteens averaged from a few dozen to several hundred on a daily basis. ${ }^{72}$

The activities of some of the women's associations were neither consistent nor longterm. As has already been mentioned in Chapter 1, the outbreak of war acts as a

68 Panevėžio katalikių moterų kareiviams šelpti komitetas. Karys, 1938-12-22, nr. 51, p. 1479.

69 PABEDINSKAITĖ, Ona. Atsiminimai iš kovų dèl Lietuvos Nepriklausomybès. In Tiesos ir meilés tarnyboje..., p. 134-134.

70 Gen. Itn. Vlado Nagevičiaus telefonograma nr. 797/c Kèdainių karo komendantui, 1920-11-13. LCVA, f. 4, ap. 1, b. 21, I. 9 .

71 Steigiamojo Seimo narès Salomèjos Stakauskaitès raštas Vyriausiajam Lietuvos gynimo komitetui, 1920-12-06. LCVA, f. 4, ap. 1, b. 21, I. 4.

72 MARCINKEVIČIENÉ-PUTVINSKAITÉ, S[ofija]. Lietuvos moteris Nepriklausomybės kovu laikais. Karys, 1935-02-16, nr. 7 (830), p. 171. 
mobilising trigger and prompts a collective response. The activities of the women's associations that were founded at the end of 1919 started to lose their impetus as the situation on the front stabilised, and resumed in the autumn of 1920, when the Polish armed forces launched a large-scale offensive. In response to the critical situation on the front, on 27 September 1920, the political elite established the Supreme Committee for the Liberation of Lithuania (Vyriausiasis Lietuvos gelbejimo komitetas). ${ }^{73}$ The main objectives of the committee were to recruit volunteers and provide material support to the Lithuanian armed forces. ${ }^{74}$ On the same day, the leaders of the Lithuanian Catholic Women's Association initiated the establishment of a new association bringing together every Lithuanian woman, aimed at the provision of material support for the Lithuanian armed forces. ${ }^{75}$ On 3 October 1920, the representatives of a wide range of women's associations, some of which had been involved in supporting the Lithuanian army since 1918, established the Lithuanian Women's Committee to Protect the Homeland (Lietuvos moteru komitetas Tèvynei ginti, or LMKTG). ${ }^{76}$ District committees of the Supreme Committee for the Liberation of Lithuania, including women's associations in their membership, had sprung up in various regions of Lithuania even before the establishment of the LMKTG. ${ }^{77}$

At the end of 1920, with the establishment of the LMKTG, a second wave was ushered in, with enhanced participation and aims. From October to December 1920, the LMKTG made an effort to bring together regional women's associations that worked in an uncoordinated way, and to open new chapters in the provinces. ${ }^{78}$ The LMKTG set up six workshops in Kaunas to make clothes for the Lithuanian armed forces, and organised free supplies of food, tobacco, stationery and other commodities from Lithuanian-based manufacturers. It also collected donations (clothing, food and money), put together special gift parcels for festive occasions, and delivered the aid collected to the front line at their own expense. ${ }^{79}$ On 11 November 1920, a women's association operating in Panevėžys and in the surrounding area despatched two car loads of collected clothing and food supplies to the Supreme Committee for the Liberation of Lithuania. ${ }^{80}$ The activities of the female members of the LMKTG, especially in Kaunas, ${ }^{81}$ and in the districts of Kèdainiai, Panevéžys and Trakai, ${ }^{82}$ demonstrated a high level of effectiveness. During the evacuation, the LMKTG provided care for sol-

73 Vyriausias Lietuvos gynimo komitetas. 1 metai: 1920 m. rugsejo 27 d. - 1921 m. gruodžio 31 d. Kaunas, 1922, p. 3.

74 CHODAKAUSKAS, [Tadas]. Kaip sudaryti valsčiuje gynimo komitetq ir kq jis turi veikti. Panevéžys, 1920, p. 1.

75 L[IETUVOS] K[ATALIKIŲ] M[OTERŲ] DR[RAUGIJOS] CENTRO VALDYBA. Kareivių reikalais. Moteris, 1920, nr. 1, p. 16.

76 Kauno moterų surinkimas. Lietuva, 1920-10-06, nr. 216 (498), p. 2.

77 Iš Lietuvos gynimo komiteto. Lietuva, 1920-10-07, nr. 217 (499), p. 1.

78 BEGĖ. Lietuvos moterų komitetas tèvynei ginti. Moteris, 1921, nr. 4, p. 9-10.

79 LADIGIENĖ, St[efanija]. Tèvynès gynimo talkininkès. Naujoji Vaidiluté, 1938, nr. 11 (157), p. 547-548.

80 Panevėžio karo komendanto telefonograma nr. 14560, 1920-11-11. LCVA, f. 4, ap. 1, b. 21, I. 8.

81 Iš Lietuvos gynimo komiteto. Lietuva, 1920-10-07, nr. 217 (499), p. 1.

82 MARCINKEVIČIENĖ-PUTVINSKAITĖ, S. Op. cit., p. 171. 
diers, and assisted in transporting the injured at railway stations. ${ }^{83}$ The LMKTG took care of Lithuanian soldiers returning from prisoner-of-war camps, meeting them at stations, and providing meals, clothes and other necessities. ${ }^{84}$ As the scale of the activities of the women's associations increased, their activities were reported to the minister of national defence on a regular basis. ${ }^{85}$

With the termination of war, the activities of the women's associations in providing assistance to the Lithuanian armed forces visibly decreased. The regional women' associations terminated their activities in the second half of 1921, and the LMKTG in 1922. It should be noted that, with the decline of the military threat, initiatives arose to establish associations for assistance to the Lithuanian armed forces; however, they proved to be inefficient. In 1925, the Women's Committee for the Care of Wounded Soldiers (Kariams ligoniams globoti moteru komitetas) was founded, with the main aim of providing material aid to soldiers treated in hospitals and to the sick in their families. The Committee's founders included Sofija Oželienè, the wife of the head of the hospital and the medical officer Lieutenant-Colonel Kazys Oželis, Pelagèja Vaiciuškienè, the wife of the medical officer and retired general Pranas Vaiciuška, Leokadija Žemgulienè, the wife of the medical officer Captain Juozas Žemgulis, Regina Kizlauskienè, the wife of the doctor and captain Dominykas Kizlauskas, and Ona Čebelytè, a nurse at the Military Hospital and the future wife of Senior Lieutenant Juozas Jankauskas. ${ }^{86}$ Nevertheless, this committee did not perform any real work, and was liquidated a year later. ${ }^{87}$

The rough figures do not allow a comprehensive and accurate estimation of the scale of material support provided by women's associations to the Lithuanian armed forces. However, the data collected during the research suggest that the support provided by women was locally based, and focused on assistance to an actual military unit of the Lithuanian army. Operating intermittently and on a relatively short time-scale (approximately one year on average), the women's associations aimed primarily at satisfying small-scale but urgent needs of the Lithuanian armed forces (such as warm clothing and food). The support collected by the women's associations was more substantial only in the period from October to November 1920, measuring it in the general context of provision to the Lithuanian armed forces.

83 Vyriausiojo armijos gydytojo igaliojimas, 1920-12-13. LCVA, f. 4, ap. 1, b. 21, I. 6.

84 Prašymas Moterų komitetui prie Gynimo komiteto nr. 6789, 1920 m. gruodžio mèn. LCVA, f. 4, ap. 1, b. 21, I. 3.

85 Gen. Itn. Vlado Nagevičiaus telefonograma nr. 740/c Panevėžio karo komendantui, 1920-11-04. LCVA, f. 4, ap. 1, b. 21, I. 11.

86 Kariams ligoniams globoti moterų komiteto įstatai, 1925-01-10. LCVA, f. 394, ap. 1, b. 211, I. 1-2.

87 Kauno miesto ir apskrities viršininko raštas nr. 122 Piliečių apsaugos departamentui, 1926-02-26. LCVA, f. 394 , ap. 1, b. 211, I. 4. 


\section{Conclusions}

The collective initiatives of women to provide material support to the Lithuanian armed forces in 1918-1920 emerged due to the interaction of interlinked causes. In the early phase of the Wars of Independence, the provision of support was initiated by women who had a background in public and political life, and supported the political projection of an independent Lithuanian state. The Vilnius Lithuanian War Relief Committee, founded by Viktorija Landsbergienè and Ona Mašiotienè, which provided material support to the Lithuanian armed forces, was only in existence for a short time. It can be stated that, following the relocation of the nascent Lithuanian armed forces to Kaunas, the experience of charity work acquired prior to Lithuania's declaration of independence was not utilised on a large scale.

By the second half of 1919, the Lithuanian armed forces had grown numerically, with an increase in the number of women's associations aiming to support them. The emergence of these associations was triggered especially by personal appeals by army officers. A number of towns and cities saw the establishment of women's associations in the wake of visits by high-ranking officers in the Lithuanian army, and although national background and social ties played an important part in the determination to support the armed forces, it was only due to external factors that their influence was actualised. It can be claimed that the dynamics of military operations and the appeals made by representatives of the Lithuanian military proved to be key external factors that provided the momentum for women to form associations for the purpose of supporting the Lithuanian armed forces. In an effort to tackle the issue of the lack of resources, the military authorities tried to attract greater public support and involve women as potential facilitators through their social role. Personal relations with the armed forces, appeals by officers and the increased threat of war brought about a situation whereby, in the second half of 1919, women's associations supporting the Lithuanian army operated in six out of the ten largest cities by population.

Women's collective initiatives generally focused on providing essential supplies (clothing and food), supporting hospitals treating soldiers, and founding meal stations for soldiers. The activities of the women's associations in 1918-1920 partly compensated for the limitations in the operations of military supply services, and sanitation and training divisions. The activities of these associations, however, were not decisive in provisioning the Lithuanian armed forces engaged in action. The activities of women's associations were of a more down-to-earth nature, and contributed to the improvement of the conditions of soldiers' everyday lives. The collective initiatives by women were only enhanced in the autumn of 1920, when the political 
elite embarked on mobilising the greatest possible public support. In this context, the activities of women's associations operating on a voluntary basis succeeded in attracting a considerable part of society, thereby becoming a publicly visible social phenomenon.

List of previous studies quoted in the article

ALIŠAUSKAS, Kazys. Kovos dèl Lietuvos Nepriklausomybès 1918-1920. T. I. Čikaga, 1972.

ANUŠAUSKAS, Arvydas. Lietuvos slaptosios tarnybos 1918-1940. Vilnius, 1998.

ASEVIČIUS, Vytautas, et al. Lietuvos kariuomenés karininkai 1918-1953. T. III, IV, VI. Vilnius, 2003, 2004, 2006.

BALKELIS, Tomas. From Defense to Revolution: Lithuanian Paramilitary Groups in 1918 and 1919. In Paramilitarism in the Eastern Baltics, 1918-1940: Cases Studies and Comparisons (Acta Historica Universitatis Klaipedensis, vol. XXVIII). Ed. by Vytautas JOKUBAUSKAS, Vasilijus SAFRONOVAS, Vygantas VAREIKIS. Klaipèda, 2014, pp. 43-56.

BALKELIS, Tomas. Lemtingi metai. Lietuva 1914-1923 m. Vilnius, 2019.

BALKELIS, Tomas. War, Revolution and Terror in the Baltic States and Finland after the Great War. Journal of Baltic Studies, 2015, vol. 46, no. 1, pp. 1-9.

BENDIKAITĖ, Eglè. „Lai kalba žygiai ir faktai“: Panevéžio krašto žydai Nepriklausomybės kovose. In Iš Panevéžio praeities: Lietuvos nepriklausomybés gynejjai ir puoselètojai. Sud. Donatas PILKAUSKAS, Zita PIKELYTĖ. Panevėžys, 2018, p. 64-83.

GRIFFANTE, Andrea. Children, Poverty and Nationalism in Lithuania, 1900-1940. London, 2019.

HEINECKEN, Lindy. The Military, War and Society: The Need for Critical Sociological Engagement. Scientia Militaria: South African Journal of Military Studies, 2015, vol. 43, no. 1, pp. 1-16.

JANKAUSKAS, Vidmantas. Kario kelias. Generolas Kazimieras Ladiga nepriklausomybès kovose. Vilnius, 2004.

JOKUBAUSKAS, Vytautas. Periodinio leidinio turinio kiekybinè analizè: 1920-1940 m. „Trimito“ atvejis. Istorija, 2019, t. 116, nr. 4, p. 78-108.

JURÉNIENĖ, Virginija. Moteris ir demokratija kuriamoje valstybeje. Parlamento studijos, 2005, nr. 3, p. 77-105.

KAVALIAUSKAS, Vilius. Lietuvos karžygiai. Vyties Kryžiaus kavalieriai (1918-1940). T. I-VII. Vilnius, 20082015.

LAURINAVIČIUS, Česlovas. On Political Terror during the Soviet Expansion into Lithuania, 1918-1919. Journal of Baltic Studies, 2015, vol. 46, no. 1, pp. 65-76.

LESČIUS, Vytautas. Lietuvos kariuomené 1918-1920. Vilnius, 1998.

LESČIUS, Vytautas. Lietuvos kariuomené Nepriklausomybés kovose 1918-1920. Vilnius, 2004.

LESTER, David. War and Personal Violence. In Effects of War on Society. Ed. by Giorgio AUSENDA. 2nd Ed. San Marino, 2002, pp. 211-222.

LUKMINAITĖ, Solveiga. Karo sanitarijos tarnybos veikla Nepriklausomybès kovu metu (19191923 m.). Vytauto Didžiojo karo muziejus 2018 metais. Almanachas. Kaunas, 2019, p. 23-62.

PETRONIS, Vytautas. Neperkirstas Gordijaus mazgas: valstybinès prievartos prieš visuomenę Lietuvoje genezè (1918-1921). Lietuvos istorijos metraštis, 2015/1. Vilnius, 2016, p. 69-95.

RASMUSSEN, Anne. Mobilising minds. In The Cambridge History of the First World War. Ed. by Jay WINTER. Vol. 3. Cambridge, 2014, pp. 390-417.

RUKŠA, Antanas. Kovos dèl Lietuvos Nepriklausomybès. T. II. Cleveland, 1981.

RUŽANCOVAS, Aleksandras. Lenku pulkai mūsu fronte 1919-1920 metais. Kaunas, 1935.

SAFRONOVAS, Vasilijus; JOKUBAUSKAS, Vytautas; VAREIKIS, Vygantas; VITKUS, Hektoras. Didysis karas visuomeneje ir kultūroje: Lietuva ir Rytụ Prūsija. Klaipèda, 2018. 
STATKUS, Vytenis. Lietuvos ginkluotosios pajègos 1918-1940 m. Čikaga, 1986.

STEPONAITIS, Vytautas. Karas su bolševikais: Ěžerèny operacijos. Kaunas, 1920.

SURGAILIS, Gintautas. Karo archyvo I-XXX tomy bibliografija. Vilnius, 2015.

SURGAILIS, Gintautas. Lietuvos kariuomené 1918-1998. Vilnius, 1998.

TYLA, Antanas. Lietuva prie Vasario 16-osios slenksčio. Vilnius, 2004.

TRUSKA, Liudas. Lietuviai ir žydai nuo XIX pabaigos iki 1941 m. birželio. Vilnius, 2005.

MOTERYS KARE: VISUOMENINĖ PARAMA LIETUVOS KARIUOMENEI 1918-1920 METAIS

Mindaugas Sereičikas

Santrauka

Platesnès apimties tyrimu, skirtu moteru dalyvavimui Lietuvos Nepriklausomybès kare, kol kas nèra atlikta. Istoriografijoje apsiribojama kai kuriu kariniuose veiksmuose pasižymejjusių moterų biografiniais tyrimais, o pastaraisiais metais daugiau dèmesio skirta nesankcionuotam smurtui, kurio aukos buvo ir moterys. Siekiant užpildyti šią tyrimu spragą, straipsnyje analizuojama viena iš moteru dalyvavimo Nepriklausomybès kare formu - paramos teikimas Lietuvos kariuomenei. Pagrindinis tyrimo tikslas yra siekis atsakyti j klausimą, kokios priežastys paskatino moteris 1918-1920 m. kurti visuomenines organizacijas, teikusias materialinę paramą Lietuvos kariuomenei.

1918 m. pabaigoje Vilniuje pradèta formuoti Lietuvos kariuomenę ir tuo pačiu metu buvo ỉkurta pirmoji moteru organizacija, teikusi paramą formuojamiems pirmiesiems kariniams daliniams. Jos ịkūrimą lèmè trys priežastys, iš kurių pirmoji - sutampantys interesai tarp Lietuvos kariuomenės siekių ir visuomeninejje veikloje dalyvavusių moteru vidinių nuostatų. Spartų organizacijos ịsikūrimą taip pat lèmè per Pirmaji pasaulinį karą moteru sukaupta labdaringos veiklos patirtis. Taip pat šios organizacijos veiklos pradžią paskatino visuomenineje ir politinejje veikloje dalyvavusių moterų ir Lietuvos kariuomenès karininkų tarpusavio ryšiai. Visgi dèl sudètingos padèties fronte pirmosios paramą rinkusios ir Lietuvos kariuomenei ją teikusios moterų organizacijos veikla greitai nutrūko.

Nors 1919 m. pirmojoje puseje didžiausią auditoriją pasiekiančioje spaudoje moterys buvo kviečiamos remti Lietuvos kariuomenę, tačiau organizacijos kūrèsi vangiai. 1919 m. vasarą reikšmingai padidejjusi Lietuvos kariuomenè, ruošdamasi plataus masto puolimui prieš Raudonają armiją, susidūrè su ypač didele maisto ir aprangos stoka. Aukšto rango Lietuvos kariuomenès karininkai savo iniciatyva vyko į regionus ir ten rengdavo susitikimus su moterimis. Šių susitikimų metu buvo pristatoma sudetinga Lietuvos kariuomenès padètis ir prašoma isteigti moteru organizacijas, kurios materialiai paremtu Lietuvos kariuomenę. Po šiu vizitu i r regionus $1919 \mathrm{~m}$. antrojoje puseje ịsteigtos septynios moteru organizacijos. Ju j̇stiegimą, be jau minètu Lietuvos kariuomenès kreipimųsi, taip pat paskatino moterų asmeniniai ryšiai su kariuomenejje tarnavusiais vyrais: neretai iniciatyvos kurti organizaciją imdavosi tos moterys, kurios giminystès ryšiais buvo susijusios su 
Lietuvos kariuomenejje tarnavusiais karininkais ar kareiviais. Taip pat neretai ịsikūrusios moterų organizacijos pirmiausia surinktą paramą (maistą, šiltus rūbus, rūkalus) skirdavo tiems Lietuvos kariuomenès daliniams, kurie buvo suformuoti moterų organizacijos veikimo teritorijoje.

Lietuvos kariuomenę materialiai rèmusių moterų organizacijų veikloje dalyvavo ne vien lietuvès, bet ir žydės, vokietès bei lenkès. Tyrimo metu surinkti duomenys nèra pakankami, siekiant vienareikšmiškai j̨vertinti tautinès identifikacijos įtaką, nusprendžiant remti Lietuvos kariuomenę. Preliminariai galima teigti, kad tautinès identifikacijos veiksnys buvo svarbus, bet neturèjo lemiamo poveikio. Lietuvos kariuomenę rèmusių moterų organizacijose gausiai dalyvavo lietuvės, o antroji tautinè grupè buvo žydės. Jos įsitraukdavo ne vien i organizacijų valdymo organus, bet ir buvo sukūrusios vieną tautiniu pagrindu jungiančią organizaciją, kuri teikè paramą Lietuvos kariuomenei. Kitų tautinių grupių atstovių dalyvavimas buvo fragmentiškas.

Moterų organizacijų kūrimosi dinamika sutampa su karinių veiksmų dinamika fronte. Organizacijų kūrimas suintensyvejo 1919 m. antrojoje pusejje, kai Lietuvos kariuomenè dalyvavo kariniuose veiksmuose trijuose frontuose. Sparčiausiai moteru organizacijos kurtos 1919 m. rudenį, prastėjant orui ir stokojant šiltų rūbų bei dalyvaujant kariniuose veiksmuose prieš Raudonają armiją bei Rusijos Vakarų savanorių armiją (plačiau žinomą bermontininkų vardu). Nuslūgus karinei grèsmei, moterų organizacijų veiklos intensyvumas taip pat pastebimai sumažèjo. 1920 m. Lenkijos kariuomenei vykdant plataus masto puolimą prieš Lietuvos kariuomenę, fiksuojama antroji moterų organizacijų kūrimosi banga. Pasibaigus kariniams veiksmams, šių organizacijų veikla sumenko, ir nors vèliau, apie 1925 m., buvo bandymų kurti naujas organizacijas, šie bandymai nebuvo tvarūs.

1918-1920 m. Lietuvos kariuomenei paramą teikusios moterų organizacijos rinko maistą, siuvo drabužius, patalynę ir kitas būtiniausias priemones. Šios organizacijos rengdavo renginius, kuriuose už surinktas lèšas nupirkdavo Lietuvos kariuomenei reikalingų daiktų. Taip pat moterų organizacijos globojo visas karines ligonines, padėdavo laidoti mirusius karius ir steigdavo geležinkelio stotyse kariams skirtas valgyklas. Iki 1920 m. rudens moterų organizacijų teikta parama buvo lokali ir padėdavo nedideliam skaičiui karių. 1920 m. rugsèjo-gruodžio mėn. moteru surinkta materialinė parama buvo didesnè - ji panaudota finansuojant naujų karinių dalinių kūrimą ir kariuomenei reikalingų drabužių (ypač šiltų) bei masto įsigijimą. 
